DOI: https://doi.org/10.31933/jemsi.v3i3

Received: 8 November 2021, Revised: 15 Desember 2021, Publish: 1 Januari 2022

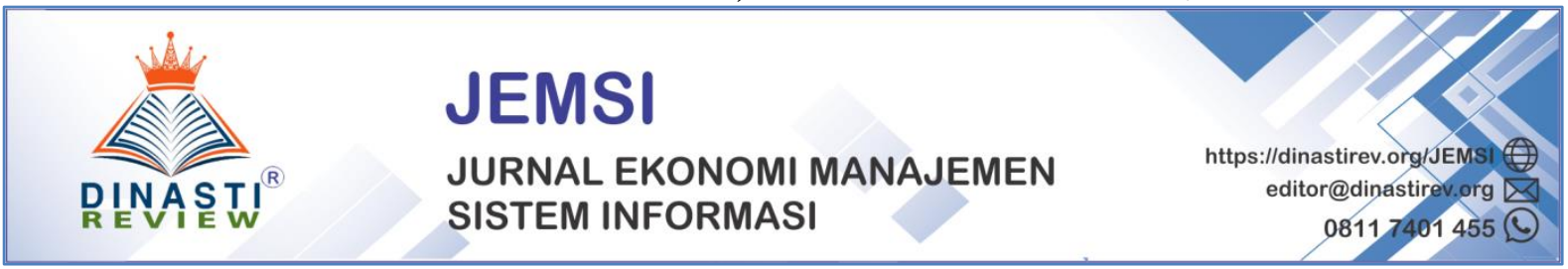

\title{
LITERATURE REVIEW KOMPONEN SISTEM INFORMASI MANAJEMEN: SOFTWARE, DATABASE DAN BRAINWARE
}

\author{
Wayan Gede Endra Bratha ${ }^{1}$ \\ ${ }^{1)}$ Mahasiswa Program Magister Manajemen, Universitas Bhayangkara Jakarta Raya, email: \\ endrabratha@gmail.com
}

Korespondensi Penulis: Wayan Gede Endra Bratha

\begin{abstract}
Sistem informasi lebih mendalam disebut sub sistem, dengan kata lain yaitu bagian yang lebih spesifik dari suatu sistem lainnya yang lebih besar lagi. Sistem informasi memiliki keterkaitan dan keterikatan sehingga tidak dapat dipisahkan dari sub sistem yang lain. Sistem informasi hanyalah satu bagian dari beberapa sub sistem yang ada dan dikelola sebagai hak milik oleh sebuah lembaga, organisasi atau perusahaan. Riset terdahulu atau riset yang relevan berfungsi untuk memperkuat teori ataupun fenomena hubungan dengan pengaruh antar variabel. Artikel disusun dengan metode kualitatif yang bersumber dari literatur penelitian terdahulu dari para peneliti, dengan hasil review yang meneliti mengenai komponen yang mempengaruhi Sistem Informasi Manajemen, yaitu: Software, Database dan Brainware. Hasil artikel literature review ini adalah: 1) Software berpengaruh terhadap Sistem Informasi Manajemen; 2) Database berpengaruh terhadap Sistem Informasi Manajemen; dan 3) Brainware berpengaruh terhadap Sistem Informasi Manajemen.
\end{abstract}

Keyword: Sistem Informasi Manajemen, Software, Database dan Brainware

\section{PENDAHULUAN}

\section{Latar Belakang Masalah}

Kemajuan teknologi dan informasi yang berkembang pesat serta arus informasi yang beredar dengan kecepatan tinggi hingga tak terbatas (unlimited) menandai munculnya era informasi. Setiap informasi baik itu merupakan informasi biasa maupun informasi rahasia dari suatu negara akan mudah disampaikan dan diketahui dengan cepat oleh masyarakat, penduduk atau warga disegala penjuru dunia. Semua jenis informasi akan terpampang dengan jelas dan transparan.

Seiring dengan arus globalisasi yang terjadi diseluruh dunia, kebutuhan informasipun semakin penting dan mutlak. Keberhasilan dalam penyampaian suatu informasi sangat bergantung dengan kondisi sarana dan prasarana yang mendukung. Pengoperasian perangkat komputer maupun teknologi informasi pada kehidupan jaman sekarang ini bukanlah hal yang awam dikalangan masyarakat, justru hal tersebut sudah menjamur luas dikalangan 
masyarakat. Bukan hanya sebatas perkembangan dalam bidang teknologi informasi saja, pada setiap perusahaan sekarang ini bahkan diwajibkan agar mampu membuat suatu upaya pengendalian internal di masing-masing ruang lingkup kerja bagian. Perkembangan teknologi informasi yang begitu signifikan ini memberikan sebab akibat yang besar dalam segala aspek kehidupan, antara lain pada golongan dalam bermasyarakat, baik kalangan individu, kalangan organisasi, maupun kalangan instansi lainnya yang juga berupaya agar mampu beradaptasi dengan optimal.

Perkembangan pada ilmu teknologi informasi sudah mampu membentuk paradigma modern atau cara pandang yang tidak hanya satu sisi dan gaya hidup milenial bagi masyarakat Indonesia khususnya saat melaksanakan aktifitas kegiatan harian di berbagai aspek kehidupan dan bidang, namun kekurangan masih terletak pada sumber daya manusianya dikarenakan masih belum mampu mengimbangi dengan baik terhadap perkembangan yang terjadi.

Pada era modernisasi saat ini, sistem informasi semakin diperlukan pada setiap organisasi, lembaga atau badan usaha, terlebih spesifik digunakan untuk meningkatkan kelancaran arus informasi, stabilitas kualitas serta kerjasama tim yang baik dengan pihak lainnya. Organisasi, lembaga atau badan usaha yang telah menerapkan sistem otomatisasi pada setiap fungsi manajerialnya, tetap disarankan agar mengikuti perkembangan teknologi dengan membangun Sistem Informasi Manajemen yang berintegrasi atau memiliki kaitan antar komponennya. Sistem Informasi Manajemen diharapkan nantinya akan memfasilitasi perusahaan-perusahaan tersebut dalam mengintegrasikan data perusahaan, meningkatkan kualitas informasi yang dimiliki dan menjadikan kontrol manajemen serta mempercepat pengolahan data perusahaan, sehingga sebagian pekerjaan rutin dapat diotomatisi dan dapat mendorong terciptanya inovasi pada produk-produk perusahaan, meningkatkan pelayanan dan kontrol, serta mempersingkat siklus alur kerja. Dalam hal ini dapat disebut bahwa Sistem Informasi Manajemen beserta perkembangan teknologi pendukungnya akan dapat memicu terjadinya transformasi besar dalam bidang bisnis dan manajemen.

Dalam artikel ini lebih lanjut akan membahas komponen-komponen Software, Database dan Brainware, berpengaruh terhadap Sistem Informasi Manajemen.

\section{Rumusan Masalah}

Dengan dasar pertimbangan uraian latar belakang permasalahan di atas, maka dapat ditetapkan rumusan masalah yang selanjutnya dibahas pada artikel literature review berikut bertujuan untuk lebih terfokuskan pada kajian teori, pembahasan dan kesimpulan nanti, yaitu:

1. Apakah komponen Software berpengaruh terhadap Sistem Informasi Manajemen?

2. Apakah komponen Database berpengaruh terhadap Sistem Informasi Manajemen?

3. Apakah komponen Brainware berpengaruh terhadap Sistem Informasi Manajemen?

\section{KAJIAN TEORI \\ SISTEM INFORMASI MANAJEMEN}


Sistem merupakan suatu tatanan yang terdiri dar sejumlah. komponen fungsional dengan tugas atau fungsi khusus yang berkaitan dan kemudian secara bersama-sama memiliki tujuan untuk memenuhi suatu proses atau pekerjaan tertentu (Alzedan, 2019). Informasi adalah hasil dari pengolahan sebuah model, farmasi, organisasi atau suatu perubahan data yang memiliki sebuah nilai tertentu, dan dapat menambah pengetahuan bagi yang menerimanya (Angga \& Eko Budi, 2017). Dalam hal ini, informasi dapat dianggap sebagai suatu subjek yang bermanfaat bagi penerimanya. Informasi juga disebut sebagai hasil pengolahan atau pemrosesan data. Sedangkan Manajemen merupakan suatu rangkaian aktivitas yang terdiri atas perencanaan, pelaksanaan, pengawasan serta pengendalian agar tercapainya suatu tujuan tertentu yang telah ditargetkan melalui pemanfaatan sumber daya manusia dan sumber-sumber lainnya (Julian, 2020). Menurut O'Brien (2010), sistem informasi manajemen merupakan kombinasi yang teratur antara people, hardware, software, communication network dan data resources yang mengumpulkan, mengubah dan menyebarkan informasi dalam organisasi.

Sistem informasi manajemen merupakann suatu metode yang disusun guna memberikan suatu informasi yang tepat waktu untuk manajemen yang berkaitan dengan lingkungan di luar organisasi dan juga kegiatan operasi di dalam suatu organisasi yang bertujuan untuk memberikan suatu kemudahan bagi proses manajemen dan memperbaiki proses perencanaan dan pengawasan serta menunjang proses pengambilan keputusan. Pada dasarnya istem informasi dapat dibedakan menjadi dua, yaitu sistem yang terstruktur (formal) dan sistem yang tidak terstruktur (nonformal). Sistem formal merupakan suatu sistem yang dijalankan sesuai dengan norma-norma organisasi yang berlaku untuk semua kalangan masyarakat, sesuai dengan kedudukannya dalam sebuah organisasi. Sistem formal ini bergantung pada tugas, wewenang, serta tanggung jawab yang telah dibebankan kepada pejabat organisasi. Sedangkan sistem nonformal merupakan sistem yang berlaku pada suatu lingkungan organisasi melalui saluran-saluran yang tidak resmi, akan tetapi masih mempunyai pengaruh yang cukup kuat dalam kehidupan organisasi tersebut.

Menurut (Susanto, 2016) komponen dalam sebuah informasi manajemen yang terintegrasi dalam sebuah sistem yang bekerja secara harmonis guna menghasilkan suatu informasi yang dapat diandalkan oleh para pemakai. Dalam konsep sistem informasi manajemen, semua unsur dan sub-unsur yang terkait dalam pembentukan suatu sistem informasi manajemen yang berkualitas harus diintegrasikan dengan baik. Unsur-unsur tersebut dapat pula disebut sebagai komponen sistem informasi akuntansi yang terdiri atas hardware, software, brainware, prosedur, database dan jaringan komunikasi.

Adapun komponen sistem informasi manajemen menurut (Susanto, 2016) yaitu;

1) Hardware merupakan peralatan fisik yang dapat digunakan dalam proses pengumpulan, pemasukan, penyimpanan, dan pengeluaran hasil pengolahan data dalam bentuk informasi;

2) Software yaitu kumpulan dari beberapa program yang dapat digunakan dalam menjalankan komputer atau aplikasi tertentu pada sebuah komputer; 
3) Brainware yaitu bagian terpenting atau utama dari komponen.suatu sistem informasi manajemen;

4) Prosedur yaitu suatu rangkaian aktivitas atau kegiatan yang dilakukan secara berulang-ulang dengan cara yang sama;

5) Basis data yaitu suatu pengorganisasian dari sejumlah data yang memiliki keterkaitan atau hubungan sehingga dapat memudahkan proses pencarian suatu informasi; dan

6) Jaringan komputer dan komunikasi data.

Berdasarkan uraian di atas dapat disintesiskan bahwa Sistem informasi merupakan suatu sub sistem yang menjadi bagian dari sebuah sistem lain yang lebih besar. Sistem informasi merupakn salah satu dari beberapa sub sistem yang dimiliki oleh sebuah organisasi Sebuah sistem informasi tidak dapat dibuat, dirancang dan dioperasikan secara terpisah dari sub sistem yang lain. Dengan kata lain, bahwa Sistem Informasi Manajemen dapat diartikan sebagai suatu sistem informasi yang digunakan untuk menghasilkan suatu nformasi yang memiliki kualitas untuk membantu manajemen dalam proses pengambilan keputusan.

Sistem Informasi Manajemen sudah ada beberapa penelitian yang dilakukan sebelumnya diantaranya: (Agustina, 2019; Alfriza Frisdayanti, 2019; Julian, 2020; Latif \& Pratama, 2015; Listiyono, 2008; Nofa, 2018; Santosa, 2014; Sidh, 2013; Simanullang, 2021; Topan et al., 2015)

\section{SOFTWARE}

Pengertian software (perangkat lunak) menurut. Roger S. Pressman (2002), merupakan sebuah perintah program dalam sebuah komputer, yang apabila dieksekusi oleh usernya akan memberikan fungsi dan unjuk kerja seperti yang diharapkan oleh usernya. Dari pengertian tersebut software memiliki fungsi untuk memberi suatu perintah kepada komputer, agar komputer tersebut beroprasi secara maksimal, sesuai dengan keingnan dari pengguna atau user yang memberikan perintah.

Menurut Melwin Syafrizal Daulay (2007:22) dalam buku nya. dengan judul "Mengenal Hardware-Software dan Pengelolaan Instalasi Komputer" software merupakan sebuah perangkat yang memiliki fungsi sebagai pengatur aktivitas kerja komputer dan seluruh intruksi yang mengarah pada sistem komputer. Kemudian dijelaskan pula bahwa software merupakan. perangkat yang menjembatani interaksi user dengan komputer yang menggunakan bahasa mesin.

Software adalah bagian sistem komputer yang tidak memiliki wujud. Software juga bisa memiliki pengertian sebagai data yang berformat digital dan disimpan secara digital yang hanya bisa dibaca oleh komputer (Julian, 2020).

Menurut (Davis, 1999), software merupakan suatu program yang berisi kumpulan intruksi atau perintah untuk melakukan proses pengolahan data. Software digunakan sebagai penghubung antara pengguna atau user dalam hal ini manusia dengan perangkat keras. 
Komputer, dengan cara menerjemahkan bahasa manusia ke dalam bahasa mesin sehingga perangkat keras komputer dapat menjalankan instruksi dan memahami keinginan pengguna yang selanjutnya memberikan hasil yang diinginkan oleh manusia tersebut.

Berdasarkan data di atas dapat disintesiskan dalam konteks ini manusia membuat suatu teknologi bernama software yang berisikan suatu urutan perintah atau instruksi untuk menjalankan berbagai komponen perangkat keras secara operasional dan akurat dan optimal. Dalam perkembangannya, software terbagi menjadi dua jenis besar, yaitu: System Software yang memiliki pengertian Software yang berisi seperangkat instruksi atau perintah-perintah untuk menjalankan berbagai komponen hardware; dan Application Software atau Software yang berisi perintah-perintah untuk mengoperasikan suatu prosedur tertentu yang merepresentasikan proses, aktivitas, dan/atau fungsi bisnis tertentu

Variabel Software sudah ada beberapa penelitian yang dilakukan sebelumnya diantaranya: (Agustina, 2019; Julian, 2020; Latif \& Pratama, 2015; Listiyono, 2008; Topan et al., 2015; Zahran, 2020)

\section{DATABASE}

Database (Basis Data) terdiri dari kata basis dan data. Basis disebut juga sebagai markas, gudang atau tempat pengumpulan. Sedangkan data merupakan catatan atas kumpulan fakta dunia nyata yang mewakili objek seperti manusia, barang, hewan, konsep, peristiwa dan lain sebagainya yang diwujudkan dalam bentuk huruf, angka, simbol, gambar, teks, bunyi atau kombinasi lainnya. (Rachmadi, 2020).

Basis data merupakan kumpulan dari data yang memiliki hubungan antara satu dengan yang lainnya, tersimpan pada perangkat keras komputer dan dapat digunakan perangkat lunak untuk memanipulasinya (Sauerwein \& Dalton, 1985). Dari definisi ini, terdapat tiga hal yang berhubungan dengan basis data, yaitu sebagai berikut:

1. Data yang terdapat dalam komputer itu sendiri yang diorganisasikan dalam bentuk basis data;

2. Simpanan permanen (storage) digunakan untuk menyimpan basis data tersebut. Simpanan ini merupakan salah satu bagian dari teknologi perangkat keras yang digunakan pada sistem informasi. Simpanan permanen pada umumnya berupa sebuah hard disk;

3. Perangkat lunak untuk memanipulasi data. Perangkat lunak ini dapat dibuat sendiri dengan menggunakan bahasa pemrograman komputer atau dibeli dalam bentuk suatu paket. Banyak paket perangkat lunak yang disediakan untuk memanipulasi basis data. Paket perangkat lunak ini disebut dengan database manajemen sistem.

Database merupakan suatu kumpulan beberapa tabel yang saling berhubungan satu dengan lainnya, hubungan atau relasi tersebut dapat ditunjukkan sebagai kunci pada setiap 
tabel tersebut. Satu database dapat menunjukkan satu populasi data yang digunakan dalam satu unit kerja suatu lembaga, perusahaan atau organisasi.

Menurut (Pane, 2020) secara garis besar, basis data. Merupakan kumpulan informasi yang disimpan pada komputer secara sistematik sehingga dapat diperiksa dikemudian hari menggunakan suatu program komputer untuk.mendapatkan informasi dari basis data tersebut.

Menurut (Abdulloh, 2018), Database atau basis data adalah kumpulan. informasi yang disimpan dalam sebuah komputer secara sistematik sehingga mampu diperiksa menggunakan suatu program komputer untuk memperoleh suatu informasi.

Dapat disintesiskan dalam konteks ini, basis data dikelola secara langsung oleh software yang disebut. DBMS (Database Management System). Basis Data jika digabungkan dengan pengelolanya atau DBMS akan menghasilkan sebuah sistem. Dalam pembuatan sebuah Sistem Basis Data memiliki tingkatan atau level bagaimana dalam melihat data di sebuah Sistem Basis Data. Tingkatan atau level, yaitu: Level Fisik (Physical Level), Level Konseptual (Conceptual Level) dan Level Penampakan (View Level).

Variabel Database sudah ada beberapa penelitian yang dilakukan oleh peneliti sebelumnya diantaranya : (Agustina, 2019; Julian, 2020; Latif \& Pratama, 2015; Listiyono, 2008; Nofa, 2018)

\section{BRAINWARE}

Brainware disebut juga pengguna merupakan suatu sebutan bagi orang yang memiliki keterkaitan dalam pengolahan data pada komputer. Akan tetapi tidak setiap sebutan user adalah Brainware. User dikatakan sebagai Brainware apabila user tersebut bukan hanya sebagai seorang pengguna melainkan juga melakukan pengolahan data pada sebuah komputer. Komponen-komponen tersebut tidak dapat dihilangkan ataupun dipisahkan, namun harus saling berhubungan serta membentuk satu kesatuan. Apabila terdapat kekurangan salah satu komponen, atau tidak lengkap, maka komputer tersebut hanyalah benda mati yang tidak dapat menghasilkan suatu apapun (Sidh, 2013).

Dalam bukunya yang berjudul sistem informasi manajemen (Susanto, 2016), menyebutkan bahwa Brainware merupakan sumber daya yang memiliki keterlibatan dalam proses penyusunan, pengumpulan, pendistribusian, pengolahan data dan pemanfaatan informasi yang dihasilkan oleh suatu sistem informasi.

Brainware berperan menjadi unit yang menangani sistem informasi manajemen diperuntukan untuk menjelajahi kemampuan pada hardware dan software yang terdapat dalam piranti komputer. Brainware memiliki berbagai macam fungsi antara lain adalah 
sebagai pengguna komputer, melaksanakan input dan output data, dan juga melakukan penyusunan pada perangkat lunak dan perangkat keras komputer.

Berdasarkan sumber data diatas dapat disentesiskan. Brainware (Pengguna) dapat disebut sebagai sumber daya manusia yang menggerakkan/mengoperasikan semua Sistem Informasi Manajemen yang dalam hal sudah mencakup Database dan Software.

Variabel Brainware sudah ada beberapa penelitian yang dilakukan sebelumnya diantaranya: (Alfriza Frisdayanti, 2019; Julian, 2020; Listiyono, 2008; Nofa, 2018; Santosa, 2014; Sidh, 2013; Simanullang, 2021; Zahran, 2020)

Tabel 1: Penelitian terdahulu

\begin{tabular}{|c|c|c|c|c|}
\hline No & $\begin{array}{l}\text { Author } \\
\text { (tahun) }\end{array}$ & Hasil Riset terdahulu & $\begin{array}{c}\text { Persamaan } \\
\text { dengan } \\
\text { artikel ini }\end{array}$ & $\begin{array}{c}\text { Perbedaan } \\
\text { dengan } \\
\text { artikel ini }\end{array}$ \\
\hline 1 & $\begin{array}{c}\text { (Listiyono } \\
\text {, 2008) }\end{array}$ & $\begin{array}{l}\text { 1. Komponen-komponen sumber daya informasi } \\
\text { terdiri. dari hardware, software, brainware, } \\
\text { database, pemakai (end user), fasilitas, informasi. } \\
\text { 2. Perencanaan strategis sumber daya informasi } \\
\text { adalah perencanaan strategis area fungsional jasa } \\
\text { informasi untuk mendukung pencapaian tujuan } \\
\text { organisasi. } \\
\text { 3. Ada } 2 \text { (dua) pendekatan yang dapat digunakan } \\
\text { untuk membuat perencanaan strategis sumber daya } \\
\text { informasi yaitu pendekatan transformasi kumpulan } \\
\text { strategi dan pendekatan strategic Planning for } \\
\text { Information Resources. }\end{array}$ & $\begin{array}{l}\text { Software, } \\
\text { Database dan } \\
\text { Brainware } \\
\text { berpengaruh } \\
\text { terhadap } \\
\text { Sistem } \\
\text { Informasi } \\
\text { Manajemen }\end{array}$ & - \\
\hline 2 & $\begin{array}{l}\text { (Sidh, } \\
\text { 2013) }\end{array}$ & $\begin{array}{l}\text { Brainware memiliki berpengaruh dalam pelaksanaan } \\
\text { Sistem Informasi Manajemen yang begitu signifikan } \\
\text { digunakan agar mampu memperoleh suatu informasi } \\
\text { dengan detail, akurat, tepat waktu dan tentunya harus } \\
\text { relevan sesuai apa yang menjadi tujuan dari lembaga, } \\
\text { organisasi atau perusahaan agar diperoleh keunggulan } \\
\text { kompetitif yang berkelanjutan ke depannya. }\end{array}$ & $\begin{array}{l}\text { Brainware } \\
\text { berpengaruh } \\
\text { terhadap } \\
\text { Sistem } \\
\text { Informasi } \\
\text { Manajemen }\end{array}$ & $\begin{array}{l}\text { Database dan } \\
\text { Software } \\
\text { berpengaruh } \\
\text { terhadap } \\
\text { Sistem } \\
\text { Informasi } \\
\text { Manajemen }\end{array}$ \\
\hline 3 & $\begin{array}{l}\text { (Santosa, } \\
2014)\end{array}$ & $\begin{array}{l}\text { Keterlibatan pengguna dalam sistem informasi, } \\
\text { ukuran organisasi, dukungan manajemen puncak, } \\
\text { kemampuan teknik personal dalam sistem informasi, } \\
\text { serta strategi yang tepat dalam pengembangan sistem } \\
\text { informasi yang berpengaruh kearah positif sehingga } \\
\text { berakibat signifikan terhadap kinerja pengelolaan } \\
\text { sistem informasi manajemen di STIMIK Duta Bangsa } \\
\text { Surakarta, baik secara parsial maupun simultan. }\end{array}$ & $\begin{array}{l}\text { Brainware } \\
\text { berpengaruh } \\
\text { terhadap } \\
\text { Sistem } \\
\text { Informasi } \\
\text { Manajemen }\end{array}$ & $\begin{array}{l}\text { Database dan } \\
\text { Software } \\
\text { berpengaruh } \\
\text { terhadap } \\
\text { Sistem } \\
\text { Informasi } \\
\text { Manajemen }\end{array}$ \\
\hline
\end{tabular}




\begin{tabular}{|c|c|c|c|c|}
\hline 4 & $\begin{array}{l}\text { (Latif \& } \\
\text { Pratama, } \\
2015 \text { ) }\end{array}$ & $\begin{array}{l}\text { 1. Sistem informasi manajemen kearsipan yang } \\
\text { memiliki database dan berbasis komputer, } \\
\text { diharapkan akan mampu menyelesaikan masalah- } \\
\text { masalah yang dialami oleh perusahaan. } \\
\text { 2. Aplikasi Microsoft access dapat digunakan } \\
\text { sebagai media yang menangani arsip dalam bentuk } \\
\text { elektronik (file). } \\
\text { 3. Terdapat pengoperasian database dengan piranti } \\
\text { komputer dengan penggunaan aplikasi Microsoft } \\
\text { access sehingga mempermudah pendataan } \\
\text { dokumen yang diperlukan perusahaan. } \\
\text { 4. Berbagai jenis laporan tertulis yang telah } \\
\text { dikerjakan berbasis Microsoft access sehingga bisa } \\
\text { dikerjakan dengan lebih cepat, akurat dan relevan } \\
\text { terhadap apa yang menjadi tujuan laporan tersebut. }\end{array}$ & $\begin{array}{l}\text { Database dan } \\
\text { Software } \\
\text { berpengaruh } \\
\text { terhadap } \\
\text { Sistem } \\
\text { Informasi } \\
\text { Manajemen }\end{array}$ & $\begin{array}{l}\text { Brainware } \\
\text { berpengaruh } \\
\text { terhadap } \\
\text { Sistem } \\
\text { Informasi } \\
\text { Manajemen }\end{array}$ \\
\hline 5 & $\begin{array}{l}\text { (Topan et } \\
\text { al., 2015) }\end{array}$ & $\begin{array}{l}\text { 1. Sistem Informasi Manajemen Rumah Sakit dalam } \\
\text { bentuk website yang telah diperoleh pada } \\
\text { perancangan ini dapat menjadi sarana yang } \\
\text { berguna sebagai penglolaan data-data pasien rumah } \\
\text { sakit, yang melaksanakan perawatan jalan maupun } \\
\text { perawatan inap, pelayanan customer di apotik } \\
\text { hingga pada pelayanan pembayaran atau kasir. } \\
\text { Pada setiap unit kerja tersebut dapat merekapitulasi } \\
\text { data-data pasien maupun data terkait keuangan } \\
\text { rumah sakit. } \\
\text { 2. Komunikasi yang terarah dengan pihak manajemen } \\
\text { sebelum sistem diterjemahkan ke dalam Bahasa } \\
\text { pemrograman harus dilakukan untuk menghasilkan } \\
\text { suatu sistem informasi manajemen yang sesuai } \\
\text { kebutuhan manajemen rumah sakit. Komunikasi } \\
\text { yang baik antara kedua belah pihak akan } \\
\text { menghasilkan suatu informasi-informasi yang } \\
\text { dibutuhkan guna menganalisa kebutuhan } \\
\text { manajemen rumah sakit. } \\
\text { Kemampuan bahasa pemrograman web seperti } \\
\text { PHP, HTML, CSS dan javascript sangat dalam } \\
\text { perancangan suatu sistem informasi manajemen } \\
\text { rumah.sakit berbasis web, agar sistem dapat } \\
\text { diselesaikan dengan lebih efisien baik dari segi } \\
\text { waktu maupun kode sumber sistem. }\end{array}$ & $\begin{array}{l}\text { Software } \\
\text { berpengaruh } \\
\text { terhadap } \\
\text { Sistem } \\
\text { Informasi } \\
\text { Manajemen }\end{array}$ & $\begin{array}{l}\text { Database dan } \\
\text { Brainware } \\
\text { berpengaruh } \\
\text { terhadap } \\
\text { Sistem } \\
\text { Informasi } \\
\text { Manajemen }\end{array}$ \\
\hline
\end{tabular}




\begin{tabular}{|c|c|c|c|c|}
\hline 6 & $\begin{array}{l}\text { (Nofa, } \\
2018)\end{array}$ & $\begin{array}{l}\text { 1. Menurunnya kinerja pegawai pada sekolah Islam } \\
\text { Al-fauzien dilatarbelakangi oleh penggunaan } \\
\text { media kertas dalam menjalankan manajemen } \\
\text { sekolah, yang menyebabkan beberapa masalah } \\
\text { diantaranya dalam birokrasi antar bagian, } \\
\text { pembuatan laporan, dan juga pencarian data yang } \\
\text { memakan waktu } \\
\text { 2. Manajemen sekolah islam al-fauzien telah } \\
\text { terkomputerisasi dengan aplikasi berbasis web } \\
\text { yang menyebabkan birokrasi antar bagian, } \\
\text { pembuatan laporan, sampai pencarian data menjadi } \\
\text { lebih efisien sehingga dapat meningkatkan kinerja } \\
\text { pegawai. }\end{array}$ & $\begin{array}{l}\text { Software, } \\
\text { Database dan } \\
\text { Brainware } \\
\text { berpengaruh } \\
\text { terhadap } \\
\text { Sistem } \\
\text { Informasi } \\
\text { Manajemen }\end{array}$ & - \\
\hline 7 & $\begin{array}{l}\text { (Alfriza } \\
\text { Frisdayanti, } \\
\text { 2019) }\end{array}$ & $\begin{array}{l}\text { Brainware mempunyai pengaruh yang signifikan } \\
\text { terhadap pelaksanaan Sistem. Manajemen Informasi }\end{array}$ & $\begin{array}{l}\text { Brainware } \\
\text { berpengaruh } \\
\text { terhadap } \\
\text { Sistem } \\
\text { Informasi } \\
\text { Manajemen }\end{array}$ & $\begin{array}{l}\text { Software dan } \\
\text { Database } \\
\text { berpengaruh } \\
\text { terhadap } \\
\text { Sistem } \\
\text { Informasi } \\
\text { Manajemen }\end{array}$ \\
\hline 8 & $\begin{array}{l}\text { (Agustina, } \\
\text { 2019) }\end{array}$ & $\begin{array}{l}\text { 1. Sistem Informasi Manajemen Presensi Karyawan } \\
\text { telah berhasil dibangun guna memberikan bantuan } \\
\text { kepada HRD dalam merekap data presensi } \\
\text { karyawan berdasarkan periode waktu tertentu } \\
\text { sesuai dengan keinginan HRD. } \\
\text { 2. Sistem Informasi Manajemen Presensi } \\
\text { Karyawanmemliki kesesuaian dengan kebutuhan } \\
\text { kondisi perusahaan di lapngan yang memiliki } \\
\text { periode waktu jam kerja yang berbeda- beda pada } \\
\text { setiap kategorinya. }\end{array}$ & $\begin{array}{l}\text { Software dan } \\
\text { Database } \\
\text { berpengaruh } \\
\text { terhadap } \\
\text { Sistem } \\
\text { Informasi } \\
\text { Manajemen }\end{array}$ & $\begin{array}{l}\text { Brainware } \\
\text { berpengaruh } \\
\text { terhadap } \\
\text { Sistem } \\
\text { Informasi } \\
\text { Manajemen }\end{array}$ \\
\hline 9 & $\begin{array}{l}\text { (Zahran, } \\
\text { 2020) }\end{array}$ & $\begin{array}{l}\text { Sumber Daya Manusia, Bisnis, Teknologi dan Metode } \\
\text { berpengaruh terhadap Sistem Informasi }\end{array}$ & $\begin{array}{l}\text { Brainware } \\
\text { berpengaruh } \\
\text { terhadap } \\
\text { Sistem } \\
\text { Informasi } \\
\text { Manajemen }\end{array}$ & $\begin{array}{l}\text { Software dan } \\
\text { Database } \\
\text { berpengaruh } \\
\text { terhadap } \\
\text { Sistem } \\
\text { Informasi } \\
\text { Manajemen }\end{array}$ \\
\hline
\end{tabular}




\begin{tabular}{|c|c|c|c|c|}
\hline 10 & $\begin{array}{l}\text { (Julian, } \\
\text { 2020) }\end{array}$ & $\begin{array}{l}\text { Ada banyak faktor yang dapat mempengaruhi Sistem } \\
\text { Informasi Manajemen seperti yang diambil pada } \\
\text { pembahasan diatas yaitu Database, Software dan } \\
\text { Brainware. }\end{array}$ & $\begin{array}{l}\text { Software, } \\
\text { Database dan } \\
\text { Brainware } \\
\text { berpengaruh } \\
\text { terhadap } \\
\text { Sistem } \\
\text { Informasi } \\
\text { Manajemen }\end{array}$ & - \\
\hline 11 & $\begin{array}{l}\text { (Simanulla } \\
\mathrm{ng}, 2021 \text { ) }\end{array}$ & $\begin{array}{l}\text { Perkembangan sistem informasi manajemen pada saat } \\
\text { ini telah mengubah banyak perubahan besar dalam } \\
\text { model pengambilan keputusan organisasi dan } \\
\text { manajemen di semua tingkat operasi (implementasi } \\
\text { teknis) dan kepemimpinan. Saat menulis sistem } \\
\text { informasi manajemen, ini akan membahas topik yang } \\
\text { berkaitan dengan penggunaan teknologi informasi, } \\
\text { efeknya, dan pentingnya dalam proses. pengambilan } \\
\text { keputusan manajemen. Oleh karena itu, diperlukan } \\
\text { lebih banyak pemahaman untuk meningkatkan } \\
\text { kualitas pengambilan keputusan dan untuk } \\
\text { menjelaskan metode dan pengaruhnya. Menggunakan } \\
\text { pengembangan sistem informasi manajemen dalam } \\
\text { pengambilan keputusan manajemen sistem infomasi } \\
\text { itu sendiri }\end{array}$ & $\begin{array}{l}\text { Brainware } \\
\text { berpengaruh } \\
\text { terhadap } \\
\text { Sistem } \\
\text { Informasi } \\
\text { Manajemen }\end{array}$ & $\begin{array}{l}\text { Software dan } \\
\text { Database } \\
\text { berpengaruh } \\
\text { terhadap } \\
\text { Sistem } \\
\text { Informasi } \\
\text { Manajemen }\end{array}$ \\
\hline
\end{tabular}

\section{METODE PENELITIAN}

Dalam artikel ini menggunakan metode kualitatif (Qualitative Research) dengan melakukan studi literatur atau Library Research. Mengkaji literature sesuai dengan teori yang dibahas khususnya di lingkup Studi Sistem Informasi Manajemen / Program Pascasarjana Magister Manajemen. Selain itu mengadaptasi analisis pada beberapa artikel ilmiah yang telah bereputasi dan menggabungkan hasil artikel ilmiah dari jurnal yang belum bereputasi. Hasil artikel yang dijadikan acuan kemudian dicitasi dari Mendeley dan Scholar Google.

Metode kualitatif merupakan metode yang fokus pada pengamatan yang mendalam. Oleh karenanya, penggunaan metode kualitatif dalam penelitian dapat menghasilkan kajian atas suatu fenomena yang lebih komprehensif. Penelitian kualitatif yang memperhatikan humanisme atau individu manusia dan perilaku manusia merupakan jawaban atas kesadaran bahwa semua akibat dari perbuatan manusia terpengaruh pada aspek-aspek internal individu.

Penelitian kualitatif diawali dengan sebuah ide yang dinyatakan dalam suatu pertanyaan penelitian (research questions). Pertanyaan dalam penelitian ini selanjutnya dapat digunakan untuk menentukan metode pengumpulan data serta cara untuk menganalisisnya. Metode ini bersifat dinamis, yaitu selalu terbuka terhadap adanya suatu pembaruan, penggantian atau penambahan data. Dalam penelitian kualitatif, suatu kajian teori harus dapat digunakan dengan konsisten melalui beberapa asumsi metodologis, yaitu dapat digunakan dengan metode induktif sehingga tidak mengarahkan pada pertanyaan yang 
diajukan oleh peneliti. Salah satu alasan melakukan penelitian kualitatif adalah saat tujuan penelitian yang ditentukan membutuhkan pemahaman yang lebih detail dan mendalam.

Dalam proses pengumpulan data terbagi dalam beberapa jenis metode pengumpulan data seperti observasi, studi pustaka, dan analisis visual. Selanjutnya data atau infromasi yang sudah dikumpulkan, kemudian dilakukan analisa sampai memperoleh hasil dari suatu penelitian untuk menarik sebuah kesimpulan.

\section{HASIL DAN PEMBAHASAN}

\section{Pengaruh antara variabel exogen terhadap variabel endogen}

Artikel ini menganalisis dan membahas tentang variabel-variabel Sistem Informasi Manajemen yaitu Software, Database dan Brainware.

\section{Pengaruh Software terhadap Sistem Informasi Manajemen}

Sistem informasi manajemen merupakan sistem yang begitu penting apabila dilihat dalam kaitannya dengan kepentingan informasi bagi setiap orang yang memimpin suatu unit kerja atau sebuah kegiatan tertentu dalam organisasi untuk kelancaran dalam fungsi manajerial, terutama untuk proses pengambilan keputusan. Menurut Moekijat (2007), sistem informasi manajemen merupakan suatu susunan prosedur pengolahan data yang dirancang dan dikembangkan dalam suatu lembaga, perusahaan atau organisasi, dengan maksud untuk memberikan data ataupun informasi kepada pihak manajemen atau pimpinan ketika sedang diperlukan, data ataupun informasi tersebut bersifat privasi maupun publik, sebagai dasar proses pengambilan keputusan dalam menjalankan fungsi manajerial guna tercapainya tujuan organisasi. Sedangkan menurut Stoner dan Wankel (2001), sistem informasi manajemen adalah sebuah metode formal yang menyediakan informasi akurat, kemudian informasi yang tepat waktu bagi seorang manajer, yang digunakan dalam pengambilan keputusan sehinga memudahkan fungsi perencanaan, fungsi pengendalian, dan fungsi operasional organisasi yang bersangkutan berjalan dengan efisien.

Sistem informasi manajemen juga memiliki pengertian sebagai pihak yang bertugas dalam beberapa fungsi untuk menyajikan data maupun bahan informasi yang dapat mempengaruhi operasi komputer. Sistem informasi manajemen menyediakan data maupun bahan informasi yang dibutuhan oleh manajerial sebagai kebutuhan rutin. Sistem informasi manajemen sudah ada sebelum adanya komputer yang digunakan untuk memasok kebutuhan informasi manajer atau pengambil keputusan sehingga memungkinkan mereka bekerja optimal dalam proses perencanaan dan pengendalian operasi organisasi.

Dewasa ini, sistem aplikasi dalam komputer sudah banyak mengalami pembaruan maupun peningkatan kualitas dalam beberapa komponen, diantaranya: kecepatan akses, ketelitian atau ketepatan, kapasitas kuantitas data yang bertambah. Hal ini dapat meningkatkan opsional alternatif yang lebih banyak dalam pengambilan keputusan. Oleh sebab itu, hubungan antara komponen non komputer dengan piranti komputer yang berada 
pada sistem informasi manajemen yang kompleks merupakan suatu kebutuhan mutlak yang tidak dapat ditawar.

Disaat seperti ini, sistem informasi manajemen selalu ada kaitan dengan pengolahan data maupun bahan informasi dengan piranti komputer atau berbasis online dengan wadah website untuk menyajikan kumpulan informasi bagi manajerial pada tingkat manajemen dan kebutuhan operasi dalam lembaga, perusahaan atau organisasi. Tentunya hal-hal yang berbasis komputer membutuhkan unsur Software sebagai sistem operasi piranti komputer, Hardware sebagai alat fisik yang menjalankan komputer dan Brainware sebagai sumber daya manusia yang bertugas sebagai operator komputer tersebut.

Pengoperasian sistem informasi manajemen yang tertata guna menunjang pengambilan keputusan yang objektif pada suatu lembaga, perusahaan atau organisasi menuntut beberapa elemen utama yang memadai diantaranya: (1) hardware, yaitu suatu perangkat komputer yang memadai baik secara kualitas dalam pengolahan data; (2) software, yaitu suatu program berbasis komputer yang mampu menerima instruksi atau perintah yang diberikan oleh seorang programmer dalam melaksanakan pekerjaan tertentu; dan (3) brainware, yaitu pengguna atau disebut operator yang profesional sudah memiliki kualifikasi ataupun kompetensi sesuai dengan bidang pengelolaan sistem informasi.

Variabel Software (Perangkat Lunak) dan Sistem Informasi sudah banyak diteliti oleh peneliti sebelumnya diantaranya: (Agustina, 2019; Julian, 2020; Latif \& Pratama, 2015; Listiyono, 2008; Topan et al., 2015; Zahran, 2020) .

\section{Pengaruh Database terhadap Sistem Informasi Manajemen}

Sistem informasi manajemen bukanlah hal baru, perbedaan terletak pada komputerisasinya. Jauh sebelum adanya komputer, teknik dari Sistem Informasi Manajemen sudah lama ada sebagai pusat informasi yang memungkinkan perencanaan dan pengendalian. Pada saat sekarang ini komputer menjadi lebih maju dengan bertambahnya satu atau dua dimensi, seperti kecepatan, ketelitian, dan volume data yang lebih besar. Jadi, dapat diartikan bahwa sistem informasi manajemen merupakan penerapan suatu sistem informasi yang dibutuhkan oleh semua tingkatan manajemen. Sistem database memiliki elemen-elemen penting, antara lain database sebagai suatu inti dari sebuah sistem database atau perangkat lunak yang digunakan untuk mengolah database dan perangkat keras yang digunakan sebagai pendukung dalam proses pengolahan data, serta manusia memiliki peran yang cukup penting dalam sistem tersebut. Sistem database sangat berperan penting dalam sistem informasi manajemen dimana sistem database berperan sebagai komponen sistem informasi manajemen, infrasturktur sistem informasi manajemen, sumber informasi sistem informasi manajemen, sarana untuk efisiensi sistem informasi manajemen, dan sarana untuk efektivitas sistem informasi manajemen. 
Setidaknya ada 10 (sepuluh) fungsi DBMS (Database Management System) yang digunakan untuk mengakomodir atau mengatur integritas data dalam suatu sistem diantaranya:

1. Menjaga integritas data;

2. Dijadikan sebagai kamus data;

3. Menyediakan interface untuk komunikasi;

4. Transformasi dan penyajian data;

5. Keamanan data;

6. Memungkinkan akses beberapa pengguna (multi access);

7. Penyimpanan data (Data Storage Management);

8. Menyediakan prosedur Backup dan Recovery;

9. Menyediakan bahasa akses dan pemrograman, dan manajemen transaksi.

Perangkat komputer memiliki fungsi dalam tugas pengolahan data-data semacam ini, akan tetapi sebuah sistem informasi manajemen dapat pula melaksanakan tugas-tugas lain yang lebih dari sekedar sebuah sistem pengolahan data. Sistem pengolahan informasi yang menerapkan kemampuan dari komputer bertujuan untuk menampilkan informasi bagi manajemen dan bagi pengambilan keputusan di suatu lembaga, perusahaan atau organisasi.

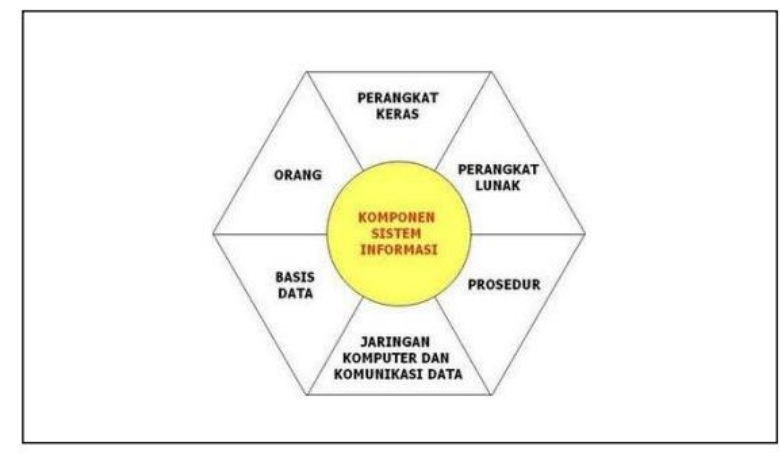

Gambar 2: Komponen Sistem Informasi Manajemen

Berikut merupakan gambaran sistem informasi manajeman dengan bentuk sebuah bangun datar segi enam dengan penjabaran dari lapisan pertama adalah informasi, penjelasan transaksi, penjelasan status, dan lain sebagainya. Pada lapisan kedua berisi sumber-sumber informasi sebagai sarana pendukung operasi manajemen sehari-hari. Lapisan ketiga merupakan sumber daya sistem informasi sebagai pendukung dalam perencanaan taktis maupun pengambilan keputusan dalam proses pengendalian manajemen. Terakhir adalah lapisan puncak memuat sumber daya informasi yang membantu proses perencanaan dan perumusan kebijakan pada tingkat manajemen.

Sistem informasi manajemen, dalam hal lain juga sebagai sebuah sistem operasi atau mesin yang terintegrasi (integrated) untuk menyajikan sistem informasi guna mendukung kinerja pada fungsi operasi, fungsi manajemen, dan pengambilan keputusan dalam suatu lembaga, perusahaan atau organisasi. Sistem informasi ini menggunakan hardware dan software komputer, prosedur pedoman, model manajemen dan keputusan, dan sebuah database. 
Variabel Database dan Sistem Informasi Manajemen sudah banyak di teliti oleh peneliti sebelumnya di antaranya adalah : (Agustina, 2019; Julian, 2020; Latif \& Pratama, 2015; Listiyono, 2008; Nofa, 2018)

\section{Pengaruh Brainware terhadap Sistem Informasi Manajemen}

Komponen-komponen sistem informasi manajemen mempunyai peranan penting dalam menghasilkan suatu sistem informasi yang relevan dengan kebutuhan. Realitanya apabila dalam pelaksanaan komponen tersebut apabila menghasilkan suatu informasi yang tidak akurat atau tidak sesuai dengan waktunya serta kurang relevan dapat mengakibatkan terjadinya kesalahan dalam pengambilan keputusan pada semua jenis ditingkat lembaga, perusahaan atau organisasi. Oleh karena itu, masih diperlukan pemahaman lebih mendalam tentang komponen apa saja yang terdapat dalam sistem informasi manajemen khususnya brainware agar informasi akurat dapat dihasilkan oleh suatu perusahaan atau organisasi agar mendapatkan sustainable competitive advantages (Sidh, 2013).

Dewasa ini, proses manajemen sumber daya manusia (SDM) yang efektif pada setiap lembaga, perusahaan atau organisasi harus dapat menciptakan manajemen sumber daya manusia yang berkompeten serta terampil untuk mengembangkan sistem informasi manajemen agar dapat memberikan pengaruh dalam proses pengambilan keputusan dalam suatu lembaga, perusahaan atau organisasi.

Berdasarkan uraian di atas, brainware memiliki pengaruh terhadap Sistem Informasi Manajemen dikarenakan sebuah sistem informasi manajemen mempunyai korelasi pada komponen-komponen yang digunakan unutk menghasilkan sebuah sistem informasi tepat dan akurat yang sesuai dengan kebutuhan pada suatu lembaga, perusahaan atau organisasi.

Variabel Brainware dan Sistem Informasi Manajemen sudah banyak di teliti oleh peneliti sebelumnya di antaranya adalah: (Alfriza Frisdayanti, 2019; Julian, 2020; Listiyono, 2008; Nofa, 2018; Santosa, 2014; Sidh, 2013; Simanullang, 2021; Zahran, 2020)

\section{Conceptual Framework}

Mengacu pada rumusan masalah artikel literature review ini, kemudian kajian studi literature review yang bersumber baik dari buku ataupun artikel yang terkait, maka digambarkan kerangka artikel ini seperti di bawah ini.

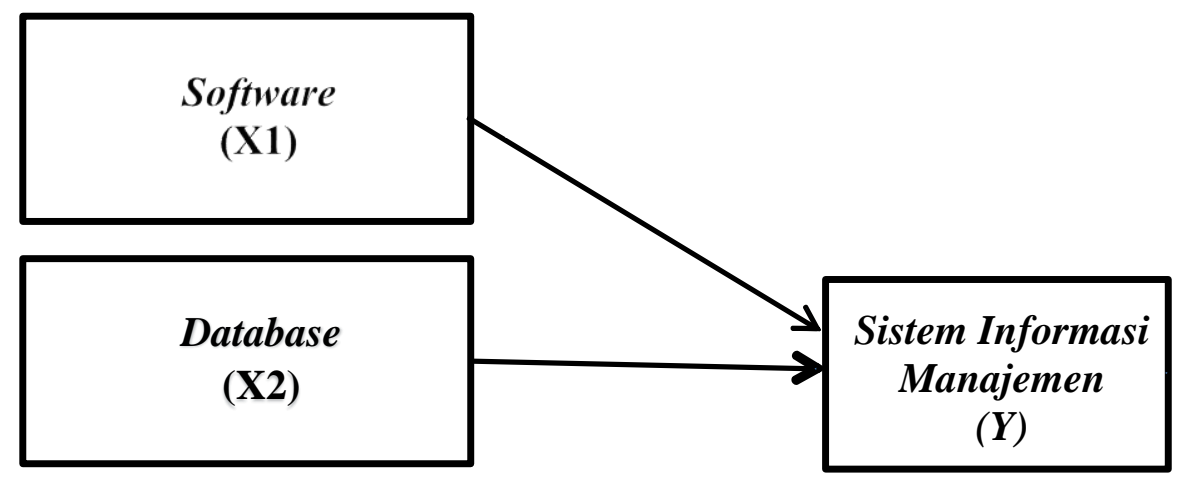




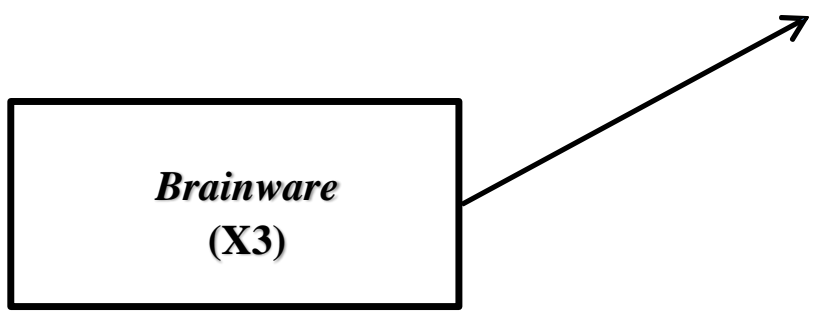

Gambar 3: Conceptual Framework

Berdasarkan data yang diuraikan pada kajian teori dan review dari hasil penelitian terdahulu yang terkait, kemudian gambar dari conceptual framework, maka dinyatakan komponen Software, Database dan Brainware memiliki pengaruh terhadap Sistem Informasi Manajemen.

Selain dari tiga variabel exogen diatas masih ada beberapa variabel yang mempengaruhi Sistem Informasi Manajemen, diantaranya:

a) Prosedur: (Alzedan, 2019; Susanto, 2016)

b) Hardware (Perangkat Keras): (Simanullang, 2021; Susanto, 2016)

c) Jaringan komputer dan komunikasi data: (Alzedan, 2019; Angga \& Eko Budi, 2017; Julian, 2020; Sudjiman, 2018)

\section{KESIMPULAN DAN SARAN}

\section{Kesimpulan}

Dengan terkumpulnya data diatas menggunakan metode kualitatif penulis mengambil kesimpulan berdasarkan rumusan masalah, maka dapat ditarik kesimpulan bahwa Software, Database dan Brainware memiliki pengaruh terhadap Sistem Informasi Manajemen. Sehingga berikut rumusan hipotesis yang dapat diambil untuk riset selanjutnya diantaranya:

1. Pengaruh Software (Perangkat Lunak) terhadap Sistem Informasi Manajemen.

2. Pengaruh Database (Basis Data) terhadap Sistem Informasi Manajemen.

3. Pengaruh Brainware (Pengguna) terhadap Sistem Informasi Manajemen.

\section{Saran}

Dari pembahasan data diatas ditemukan bahwa masih ada beberapa komponen lain dari Sistem Informasi Manajemen selain dari Software, Database dan Brainware pada semua jenis ditingkat lembaga, perusahaan atau organisasi. Dengan demikian dari penelitian ini dapat diajukan saran yaitu masih diperlukan kajian yang lebih lanjut untuk mencari komponen lain apa saja yang dapat mempengaruhi Sistem Informasi Manajemen selain variabel dalam penelitian ini. Faktor lain yang dimaksud diantaranya: Prosedur, Hardware (Perangkat Keras), Jaringan Komputer dan Komunikasi Data.

\section{DAFTAR RUJUKAN}

Abdulloh, R. (2018). 7 in 1 Pemrograman web untuk pemula. Elex Media Komputindo.

Agustina, N. (2019). Sistem Informasi Manajemen Presensi Kehadiran Karyawan Berbasis

Web. Produktif: Jurnal Ilmiah Pendidikan Teknologi Informasi, 3(2), 1-7. https://journal.umtas.ac.id/index.php/produktif/article/view/670 
Alfriza Frisdayanti. (2019). Peranan brainware dalam sistem informasi manajemen jurnal ekonomi dan manajemen sistem informasi. Jurnal Ekonomi Dan Manajemen Sistem Informasi, 1(September), 60-69. https://doi.org/10.31933/JEMSI

Alzedan, R. M. (2019). Sistem Informasi Management. https://doi.org/10.31219/osf.io/tdh8v

Angga, S., \& Eko Budi, S. (2017). Sistem Informasi Pengumuman Program Studi Di Perguruan Tinggi X. Lontar Komputer : Jurnal Ilmiah Teknologi Informasi, 8(1), 0-10.

Davis, G. B. (1999). Management Information System.

Julian, M. B. (2020). Faktor-faktor yang mempengaruhi Sistem Informasi Manajemen: Database, Software dan Brainware. Academia Letter, 11. https://www.academia.edu/44624460/Faktor_faktor_yang_mempengaruhi_Sistem_Infor masi_Manajemen_Database_Software_dan_Brainware?auto=citations\&from=cover_pag e

Latif, F., \& Pratama, aditya wirangga. (2015). Perancangan Sistem Informasi Manajemen Arsip Elektronik. Jurnal Akuntansi,Ekonomi Dan Manajemen Bisnis, 3(1), 21-31. https://jurnal.polibatam.ac.id/index.php/JAEMB/article/download/180/168

Lipursari, A. (2019). Peran Sistem Informasi Manajemen (Sim) Dalam Pengambilan Keputusan. Jurnal Stie Semarang, 53(9), 1689-1699. http://jurnal3.stiesemarang.ac.id/index.php/jurnal/article/view/154/125

Listiyono, H. (2008). Fungsi Perencanaan pada Area Fungsional Jasa Informasi. Jurnal Teknologi Informasi DINAMIK, XIII(1), 22-26.

Nofa, W. K. (2018). SISTEM INFORMASI MANAJEMEN BERBASIS WEB PADA SEKOLAH ISLAM AL-FAUZIEN. INFORMATIK Jurnal Ilmu Komputer Volume 14 Nomor 3 - Desember 2018, 14(1), 105-112.

Pane, N. S. (2020). Rancang Bangun Sistem Informasi Pencegahan Penyakit dan Penyehatan

Lingkungan Pada Puskesmas Rantau Utara Dengan Menggunakan Bahasa

Pemroggraman PHP. Jurnal Ilmiah INFOTEK, 5(2).

Rachmadi, T. (2020). SISTEM BASIS DATA. TIGA Ebook.

Rosdianti, S. (2018). Pengaruh Teknologi Informasi dan Pengendalian Internal Terhadap

Kualitas Sistem Informasi Akuntansi Manajemen Pada Bank Central Asia. Jurnal Akuntansi, Audit Dan Sistem Informasi Akuntansi, 2(3), 65-72.

Santosa, T. D. (2014). Faktor-faktor yang Berpengaruh terhadap Kinerja Sistem Informasi Manajemen. Duta.Com, 7(2), 4-6.

Sauerwein, J. C., \& Dalton, G. R. (1985). Standard reference data publications, 1964-1984.

Sidh, R. (2013). PERANAN BRAINWARE DALAM SISTEM INFORMASI MANAJEMEN. Jurnal Computech \& Bisnis, 7(1), 19-29. https://doi.org/10.1021/jf60200a019

Simanullang, P. M. (2021). Pengaruh Perangkat Keras Komputer Dalam Sistem Informasi Manajemen. 10.

Sudjiman, P. E. S. dan L. S. (2018). KOMPUTER DALAM PROSES PENGAMBILAN KEPUTUSAN Paul Eduard Sudjiman dan Lorina Siregar Sudjiman COMPUTER BASED MANAGEMENT INFORMATION SYSTEM. Jurnal TeIKa, 8, 55-67.

Susanto, A. (2016). Sistem Informasi Manajemen: Konsep dan Pengembangan Secara Terpadu (1st ed.). Lingga Jaya. 
Topan, M., Wowor, H. F., \& Najoan, X. B. N. (2015). Perancangan Sistem Informasi Manajemen Rumah Sakit Berbasis Web Studi Kasus : Rumah Sakit TNI AU Lanud Sam Ratulangi. $E$ - Journal Teknik Informatika, 6(1), 1-6. https://ejournal.unsrat.ac.id/index.php/informatika/article/viewFile/9968/9554

Zahran, R. (2020). Faktor-Faktor Yang Mempengaruhi Sistem Informasi : Sumber Daya Manusia, Bisnis, Teknologi dan Metode. Jurnal Akuntansi Universitas Mercubuana, 121.

https://www.academia.edu/download/65018601/Artikel_Literatur_Review_Faktor_Yang _Mempengaruhi_Sistem_Informasi_Ravena_Zahran_dikonversi.pdf 